http://dx.doi.org/10.11646/phytotaxa.125.1.9

\title{
Corrections to Phytotaxa 112: Update on the systematics of Benstonea (Pandanaceae)
}

\author{
MARTIN W. CALLMANDER ${ }^{1,2}$ \& SVEN BUERKI ${ }^{3}$ \\ ${ }^{1}$ Missouri Botanical Garden, P.O. Box 299, St. Louis, MO 63166-0299, U.S.A. \\ ${ }^{2}$ Conservatoire et Jardin botaniques de la ville de Genève, ch. de l'Impératrice 1, case postale 60, 1292 Chambésy, Switzerland. \\ E-mail:martin.callmander@mobot.org \\ ${ }^{3}$ Jodrell Laboratory, Royal Botanic Gardens, Kew, Richmond, Surrey, TW9 3DS, U.K.
}

After the publication of our Update on the systematics of Benstonea (Pandanaceae): When a visionary taxonomist foresees phylogenetic relationships (Callmander, Booth, Beentje \& Buerki 2013), an error was brought to our attention:

\section{Correcting an omission in citing the basionym of a combination made in Benstonea}

On page 59, we attempted to provide a new combination for Pandanus ornithocephalus Stone (1978: 64) in Benstonea Callmander \& Buerki (in Callmander et al. 2012: 328). When proposing the new combination $B$. ornithocephala (B.C. Stone) Callm. \& Buerki, comb. nov., the author of the basionym was omitted from the basionym reference and according to Art. 41.5 of the ICN (McNeill et al., 2012), a new combination is not validly published: "unless its basionym or replaced synonym is clearly indicated and a full and direct reference given to its author and place of valid publication". In our case, there is only one 1978 reference in the bibliography and we can argue that there is no ambiguity because the author of the basionym is cited in the protologue and that the combination is therefore validly published. We nevertheless prefer to correct this error here by citing a full and complete reference to the basionym to avoid further confusion:

Benstonea ornithocephala (B.C. Stone) Callm. \& Buerki, comb. nov.

Basionym: Pandanus ornithocephalus Stone (1978: 64). Type:-INDONESIA [NEW GUINEA]. West Papua Prov.: Vogelkop Peninsula [Kepala Burung], Skendi (N of Teminaboean), c. 100 m, 21 May 1958, fr., Versteegh BW7474 (holotype, L [L0050607]!)

\section{Acknowledgements}

The authors thanks Irina V. Belyaeva-Chamberlain for bringing this error to our attention and Katherine Challis for her help in this Note.

\section{References}

Callmander, M.W., Lowry II, P.P., Forest, F., Devey, D.S., Beentje, H. \& Buerki, S. (2012) Benstonea Callm. \& Buerki (Pandanaceae): characterization, circumscription, and distribution of a new genus of screw-pines, with a synopsis of accepted species. Candollea 67: 323-345.

Callmander, M.W., Booth, T.J., Beentje, H. \& Buerki, S. (2013) Update on the systematics of Benstonea (Pandanaceae): when a visionary taxonomist foresees phylogenetic relationships. Phytotaxa 112: 57-60. 
http://dx.doi.org/10.11646/phytotaxa.112.2.4

Mcneill, J., Barrie, F.R., Buck, W.R., Demoulin, V., Greuter, W., Hawksworth, D.L., Herendeen, P.S., Knapp, S., Marhold, K., Prado, J., Prud'homme van Reine, W.F., Smith, G.F., Wiersema, J.H. \& Turland, N.J. (eds.) (2012) International Code of Nomenclature for algae, fungi, and plants (Melbourne Code) adopted by the Eighteenth International Botanical Congress Melbourne, Australia, July 2011. A.R.G. Gantner Verlag, Ruggell, Liechtenstein [Regnum Vegetabile 154].

Stone, B.C. (1978) Revisio Pandanacearum, Part I. Pandanus subgenera Coronata and Acrostigma. Flora Malesiana precursores. Federation Museums Journal, new series 23: 1-74. 